\title{
Essential characteristics of national values in philosophical and psychological and pedagogical literature
}

\author{
O. Z. Glushko \\ Institute of Pedagogy of the National Academy of Educational Sciences of Ukraine, Kyiv, Ukraine \\ Corresponding author. E-mail: glushko.oks74@gmail.com
}

Paper received 11.05.18; Accepted for publication 19.05.18.

\section{https://doi.org/10.31174/SEND-PP2018-170VI70-04}

\begin{abstract}
The article clarifies the essential, general characteristics of the notions of "values" of the "nation" of "national values". The key components of the notion "nation" are determined in the view of the analysis of philosophical and psychological and pedagogical literature. This research is based on the work of world-known philosophers, psychologists, sociologists, educators, and scientists of Ukrainian diaspora.

Keywords: values, national values, nation, objective and subjective features of the nation, Ukrainian diaspora.
\end{abstract}

Introduction. The education of national values relates to a multidimensional scientific and pedagogical problem. On the one hand, in the context of the development of Ukrainian statehood, there is an urgent need to preserve national values and ideals that have been formed and accumulated over the millennial history of Ukrainian people. On the other hand, we live in a global world, the realities of which are multilingualism, multiculturalism, integration at all levels of life; all these processes certainly need new approaches in the education of young people. We want to note that globalization with the formation of a single space, in accordance with generally defined principles of coexistence, of a single normative system, without a doubt, covers all spheres of human activity, including education. At the same time, modern development of society, globalization processes, not only do not deny education on the values of patriotism, national unity. The importance of upbringing of respect for cultural values, traditions, to own history, etc., in conditions of increasing competition between states increases significantly. Thus, the upbringing of a patriot, a citizen of his/her country, which primarily involves the accession to universal and national values, remains an urgent problem today.

Literature review. A significant contribution to the study of value issues was made by national and foreign scholars, in particular, the essence and problems of the origin of values, their classification, problems of values in education were studied by V. Andrushchenko, I. Beh, I. Bychko, M. Kagan, O. Kirichuk, V. Kremen, D. Leontiev, I. Nadolny, V. Ognevyuk, O. Rogova, A. Ruchka, S. Schwartz, V. Vasilenko, etc.

The analysis of the national values of Ukrainian people is made in the works of M. Boryshevsky, S. Krymsky, G. Sitnik, Y. Surmin,V. Vasyutinsky, O. Vishnevsky and others.

The problem of the essence of a nation is highlighted in the works of the Western scholars: B. Anderson, K. Doich, F. Mayneke, E. Renan, E. Renan, E. Smith.

Significant advances in the theory of the concept of "nation", its systematization and classification are the studies of Ukrainian scholars, in particular, the researchers of the Ukrainian diaspora, namely: O. Bochkovskii, G. Vaskovich, G. Kasyanov, A. Kolodiy, I. Kresina, P. Kononenko, V. Lypynsky, I. Mirchuk, Y. Pundika, S. Rudnytsky, V. Starosolsky.

Research methods. In the article the author uses theoretical methods (analysis of scientific sources on the problem of research, synthesis, comparison, generalization).

The concept of a "value". First, let's consider the notion "value", which is central to our study. Actually the notion of a "value" was introduced into philosophical science in the 60's of the 19-th century by German philosopher R. Lotze (1817-1881). At the beginning of the 20-th century, values as a separate branch of research are distinguished in an independent theoretical discipline called "axiology" (from the

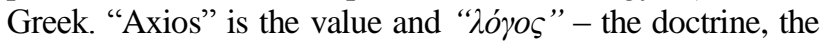
mind, the law).

The German philosopher Friedrich Wilhelm Nietzsche (1844-1900), a representative of irrationalism, features an original look at a person, existing moral and traditional values. In the work "Thus Spoke Zarathustra", he claimed that "God died" "the death of God" and from the realization of this thought begins the process of human revaluation of values [14, p. 9].

In place of the existing values, according to the philosopher, power appears as the main value, or rather, "the will to power". A principle "will to power" is embodied by the human being's will to truth. We should note that for the philosophical doctrine of F. Nietzsche the destruction of traditional values is characteristic, which, according to the philosopher, have already been exhausted. The creation of new values by German thinker was entrusted to a superman. In general, "superman" (Übermensch (German), "Superhuman" (English) - is one of the central concepts of Philosophy F. Nietzsche. "Superhuman" in their actions are not guided by commonly accepted values. It is a person who decides what is good and what is evil. In his concept, the philosopher connects the existence of a superman with the death of God, which in turn leads to the setback from the traditional, Christian values. The change, the destruction of existing values, is associated with the change of those who creates them. The Creator is definitely a Destroyer. On "superhuman", in the philosophical views of F. Nietzsche, is responsible for the creation of the completely new [14, p. 51]. It is the very existence of F. Nietzsche realized as the value of. Consequently, we see that the category of values in the philosophical views of F. Nietzsche is defined as the whole world of being, he advocates the need for a constant reassessment and review of values. The value of life is unconditional, a fundamental value in Nietzsche's philosophy.

Representatives of the Baden School of Neo-Kantianism Wilhelm Windelband (1848-1915) and Heinrich Rickert (1863-1936) founded the theory of values as the basis of their philosophical doctrine. They believed that nature appears on its own, culture - through the creation of values by man. The values were understood as something transcendent, they, according to philosophers, create "independent realm" $[16$, p. 23]. Unlike F. Nietzsche, neo-Kantian H. Rickert believed that values could not change, and the revaluation of all the values that were emphasized by German Philosopher F. Nietzsche, were not the task of science [17, p. 435]. 
One of the founders of sociology Max Weber made a great contribution to the scientific development of value issues (1864-1920). Unlike neo-Kantians, W. Windelband and H. Rickert, who attributed values to the transcendent world, $\mathrm{M}$. Weber considered values as the guiding principles of a particular historical epoch. According to the scholar, cultural ideas and values help to shape society and largely determine human behavior.

Ancient English sociologist Anthony Giddens believes that values are the perception of individuals or groups of people of what is desirable, proper, good or bad. He observes that the values of the individual are formed under the influence of the culture in which he lives [5, p. 669]. Thus, we see a direct connection between values and culture, in particular, the national culture.

American teacher John Dewey (1859-1952), a representative of pragmatism in his work, "Introduction to the philosophy of education", noted that education is a laboratory where philosophic values are specified and verified [3, p. 56]. According to the teacher, every person, due to his personal experience and education, acquires the ability to assess this experience. However, the task of parents and teachers is not only superficial, formally equip the child with the values, but first and foremost try to make them deep into the inner world of the child. Consequently, J. Dewey proclaimed the cult of the child's personality.

The American psychologist Abraham Harold Maslow (1908-1970), a representative of the humanistic approach, identified existential values that determine the meaning of human existence: integrity, perfection, completeness, justice, viability (full functioning), truth, beauty, goodness, selfsufficiency, etc. He believed that values are created or constructed. According to Maslow, values were originally inherent in human nature, they have a biological and genetic basis, but they are also developed by culture and civilization [11, p. 207].

Another representative of humanistic psychology, Carl Rogers (1902-1987), in his work "Learn to be free", advocated freedom of study: in the process of learning in a supportive climate, the student starts to rely on his own values, which he is actually experiencing, and not on those that are imposed by the other people. Thus, with this approach to learning, as the American psychologist and educator C. Rogers believed, the student first learns to be free [18, p. 57-58].

The notion of "nation" in philosophical and psychological-pedagogical literature. From values, let's turn to the consideration of the following concept - the nation. The notion of a nation, as well as the notion of value, is also complex, multicomponent and contradictory. Nation (from the Latin natio - people) the form of the community of people that has historically developed; nations are inherent in the commonality of territory and economic life, the common language, some features of the psychological and spiritual composition, manifested in the originality of culture. However, we want to note that the universal definition of the concept of a nation does not exist. It is difficult to give a complete, comprehensive definition of a nation, because it is a controversial notion.

The study challenges the nation and nation-building were engaged in such well-known Ukrainian Diaspora scientists as O. Bochkovsky, D. Dontsov, A. Knyazhinsky, O. Kulchytsky, V. Lypynsky, Y. Mirchuk, Yu. Pundyk, V. Starosolsky, V. Vaskovych, V. Yaniv whose views are based on theories of nationalism and development of West- ern European and American scientists [7, 9, 10, 20, 23, 24]. The development of the theories of nationalism, the essence of the notion of the nation, its constituent elements were devoted the works of B. Anderson, E. Gellner, É. Durkheim, G. Simmel, F. Meinecke, E. Renan, A. Smith and others.

Our task is to consider such a phenomenon as a nation, to define its characteristic features, first and foremost, to focus on the research of Ukrainian diaspora scholars, as well as to show the influence of foreign scholars dealing with the problems of nation-building, on the views of Ukrainian researchers.

The German philosopher, Johann Gottfried Herder (17441803), described the nation as a linguistic and cultural community. According to Herder, a significant sign of each nation is the language and it was he who gave a significant superiority over other elements that affect the existence and preservation of different distinctive culture [6, p. 40]. He noted that the diversity of languages not only delimits people among themselves, but also encourages them to develop their own cultures. Consequently, J. Herder substantiated the very important idea of the culture-forming function of language which was further developed by linguist W. Humboldt. Historically, the existence of a culture is ensured, as J. Herder believed, primarily through language and tradition, as a mechanism for its historical translation.

The philosopher emphasized the importance of cultural intercourse and the translation of spirituality among nations as the best way to improve the level of art, science, culture and language which in its turn encourages the further development of these peoples.

French scholar Joseph Ernest Renan (1823-1892) in his work "What is a nation?" defined the concept of a nation as a "spiritual principle", a nation from his point of view belongs to the sphere of morality and psychology. In particular, he noted that "the common victories in the past and the joint wishes in the future - these are the main conditions for the formation of a nation ..." [15, p. 118-119]. The definition given by E. Renan is considered to be one of the first classical definitions of the concept of a nation. According to the researcher, the main features of the nation are moral consciousness and will, as opposed to such commonly accepted signs as territory, race, language, religion [15]. Thus, when outlining the concept of a nation, E. Renan emphasizes the priority of subjective rather than objective factors. The value of E. Renan's work "What is a nation?" is that he was the first among researchers who identified the subjective features of the nation clearly.

The German historian Friedrich Meinecke (1862-1954) distinguished the nations as "cultural" that is, ethnic and national "political", state. Moreover, according to F. Meinecke, belonging to a cultural nation, did not depend on state borders, meanwhile belonging to a political nation, was limited by these borders [12, p. 505]. He included the components of a nation: a common territory, a common origin, a common state, a common history, language, religion, national identity. However, this does not mean that in the formation of each nation, all the above features must be present.

One of the renowned researchers of nationalism, Ernest André Gellner (1925-1995), noted the deep-seated interrelation of the nation with culture, which meant "a system of ideas, signs, relationships, behaviors, and communication" [4, p. 297]. In addition to culture, to the main features of the nation Gellner enlisted the territory, language, as well as the mutual recognition of a person belonging to the nation [4]. 
The most well-known classical works of the present, with an original look at the processes of nation-building, include the study of Benedict Anderson's "Imagined Communities". American historian B. Anderson interpreted the nation as "an imagined political community". He thought "the nation was imagined because the representatives of the nation will never know the majority of their compatriots, will not meet and will not even hear anything about them, and yet in the imagination of each will live the image of their ownership" [2, p. 22]. According to Anderson, the language is endowed with the function of nationalization.

German historian Peter Alter claimed it very difficult to give a scientific, generally accepted definition of a nation. In his work "Nation: The Problem of Definition", he described the nation as a "social group", which, on the basis of historical, linguistic, cultural, religious and political connections, realizes its unity and interests $[1$, p. 586]. To the main features of the nation, he attributed national consciousness. In addition, national consciousness, according to P. Altera, is not a kind of constant concept, it can change, as well as values. Thus, certain objective characteristics (territory, state, language, culture, religion, traditions, etc.) are not as much important to the nation, as the awareness of a person, his belonging to one or another nation, the recognition of its uniqueness and distinction from other nations. As P. Alter believed education plays a key role in this process [1].

Now let's look at the views of the Ukrainian scholars who worked on emigration in terms of their conception of a nation, where objective and subjective characteristics include this concept. The conceptual basis for the ideas of the scientists of Ukrainian diaspora on the study of the problems of nationalism, the essence of the concept of "nation", its main components were the works of world-famous philosophers, sociologists and psychologists.

Ukrainian scholar, educator, historian Boris Krupnytsky (1894-1956), as well as P. Alter, believed that the "nation" refers to a complex, "multicolored", multidimensional phenomenon. A nation is, first of all, a spirit, a "spiritual being", and then a biological being [8, p. 157]. Each historical epoch, according to B. Krupnytsky, tend to have its own understanding of the concept of "nation". He stressed the importance and interconnection of culture with the formation of national consciousness. In this context, culture, in terms of emigration, becomes crucial.

According to the writer, one of the ideologues of Ukrainian nationalism, Yuri Pundyk (1918-1973), "nation" is also a very complex, moral imperative, since, as every spiritual phenomenon, it is not subject of rational research. The main characteristic of the nation, in the opinion of the researcher is first of all, the spiritual connection with it, that is, national consciousness but not the territory and blood origin. The traditional definition of a nation, as a historical community of people living in a certain territory and bound together by blood ties, Yu. Pundyk, considered to be narrow. He noted that the nation could exist as a community without territory, but if you look at the USA, there are people of different blood origins [20].

In his work "Ukrainian nationalism" Yu. Pundyk defined the nation as "the family of brothers" [20, p. 57]. These views on the nation of a Ukrainian researcher can be compared with the views of the contemporary American sociologist B. Anderson, who emphasized that the nation "is always perceived as a deep and solidary brotherhood" [2, p. 24]. Thus, it may be noted that Pundyk as well as
Anderson, perceived the nation as something very native, even family-like.

Every person, as Yu. Pundyk believed, is spiritually tied to his nation, whether he lives in his own national environment, or not. This thesis is especially relevant in the conditions of emigration, when a person is physically not in the territory of the settlement of his people, and is outside the Motherland, but spiritually and culturally remains a representative of his nation. Ukrainian scholar referred a language to the main elements of the national affinity that, in his opinion, is an important "means of cementing the spiritual unity of the nation and its preservation". In addition to language, he related historical traditions, spiritual and cultural identity to the leading elements of the nation [20,p.45-46].

Another ideologue of Ukrainian nationalism Viacheslav Lypynsky (1882-1931), also defined the nation as a cultural and spiritual community [10, p. 99]. V. Lypynsky, as well as $\mathrm{Yu}$. Pundyk, considered the main component of the existence of a nation - a common idea and aspiration of the people for state independence [10]. He believed that the formation of a nation happens only through the state. In addition, according to V. Lypynsky, national culture serves as a unifying element for every nation. This thesis about the fundamental importance of culture in identifying a nation can also be found in the works of a famous English researcher on issues of nationalism E. Gellner. Ernest André Gellner, a well-known English researcher on nationalism, adhered to these views of the decisive importance of culture in the formation of the nation.

The Ukrainian educational and public figure Anton Knyazhynsky (1893-1960) in the work "The Spirit of the Nation: Sociological and Ethnopsychological Studio" also determined that culture has a direct influence on the formation of a nation. In his opinion, culture acts as the "most important" sign of the nation [7, p. 67]. Among other features, the researcher distinguished territory, race, traditions, language and faith.

Ukrainian diaspora scientist Volodymyr Yaniv (19081991) described the nation as "the highest holy community". Among other elements, the psychologist attached special importance to the tradition: "The cult of tradition provides the nation eternity" [24, p. 176].

Famous Ukrainian educator, Gregory Vashchenko (18781967), also attributed historical traditions to the main features of the nation. He compared the meaning of traditions in the life of mankind, with the meaning of memory for each person. According to the educator, without traditions further development of mankind would not be possible. In addition, G. Vashchenko concluded that national culture, traditions, as well as language, turn people into nation [24, p. 286]. Consequently, they are the main national formation elements. By definition of G. Vashchenko, the nation creates a community of origin, territory, language, culture, traditions. He also emphasized that the main prerequisite for the existence of the nation is national consciousness, selfidentification with its own ethnic community [22].

Olexander Kulchytsky (1895-1980) is also a prominent Ukrainian philosopher, psychologist, teacher, public figure of the Ukrainian diaspora. The sources of his philosophy were the views of I. Kant and G. Skovoroda. The scientist paid special attention to the issue of nation-building, the formation of the Ukrainian mentality, the study of Ukrainian mentality and character. In particular, he identified racial, geopsychic (geographical), historical, socio-psychic (social), cultural morphological, and psychological factors of the 
formation of Ukrainian nation. The scholar believed that national culture is the main nucleus of belonging to one or another nation. Actually, the national culture, he defined as a synthesis of values and "subjective experiences" [9, p. 22]. $\mathrm{He}$ also highlighted the main features of the nation, which enrolled: 1) the language; 2) religion; 3) culture; 4) a common historical destiny; 5) geopolitical, geographical factors that form the national mentality; 6) common origin; 7) the sense of national messianism. However, according to O. Kulchytsky, among the factors of national unity in the diaspora, religion and culture come to the foreground. At the same time, the connection with the land, that is, the territory, the experience of the common historical destiny, the feeling of a common blood (national affiliation), the language goes to the background $[9$, p. 23]. A well-known Ukrainian diaspora educator Ivan Bondarchuk, analyzing this problem, also noted that language, religion, and national traditions, in the conditions of a foreign language environment and powerful assimilation influence, are the main factors in preserving the ethnic originality of Ukrainians across the borders of the Motherland.

Ivan Ohienko (1882-1972), Metropolitan of the UAOC (Metropolitan Ilarion), a linguist, a teacher, a scientisttheologian considered the language as the main national feature and the main factor of formation the national consciousness of Ukrainians across the borders of the Motherland [13, p. 114]. In terms of emigration, language, as a visible sign of belonging to a certain group acquires a symbolic and moral value. In addition to language, the main features of the nation scientist singled out religion, culture, traditions, customs, and the history of their own people.

Ukrainian scholar, the geographer S. Rudnytsky (18771937), in the work "To the Basics of Ukrainian
Nationalism", published in 1921, defined the "nation" as an integral community of people connected with each other by "peculiar signs" [19, p. 22]. To the signs that form the nation he enlisted: national affiliation (anthropological race), language, culture (both material and spiritual), historical traditions, territory. However S. Rudnytsky, did not distinguish none of the identified features of the nation as the main one in his opinion they were all equivalent [19].

Professor of History Oleksander Shulhyn (1889-1960), also J. J. Russo and F. Minecke believed that there were objective and subjective features of the nation, among them: race, geographic environment, language, culture, religion, state, national consciousness, history. According to O. Shulhyn sense of its national "I" has great importance in the formation of a nation has, that is, national consciousness. As we noted earlier, P. Alter and E. Renan maintained the same point of view when considering the nation. Among the objective features of the nation, the scholar highlighted the language, which he gave the main national-creative function: "... the language became the basis for the creation of Ukrainian nation" [21, p. 287].

Consequently, scientists, in defining the concept of the nation, distinguished objective and subjective features of this phenomenon. Most researchers included race (national origin), state, geographical location or territory, climate, culture, language, historical memory (history), traditions, religion to objective characteristics. Subjective characteristics included: national consciousness, national messianism, freedom. However, none of the above features can be considered vital in the creation of a nation.

When considering the concept of "nation", Ukrainian diaspora researchers singled out the following characteristic features of a nation: (See Table 1).

Table 1

\begin{tabular}{|c|c|c|c|c|c|c|}
\hline Scientists & \multicolumn{5}{|c|}{ Objective features of the nation } & Subjective features of the nation \\
\hline $\begin{array}{c}\text { Anton } \\
\text { Knyazhynsky }\end{array}$ & territory & $\begin{array}{l}\text { origin } \\
\text { (race) }\end{array}$ & language & traditions & $\begin{array}{l}\text { culture, } \\
\text { religion }\end{array}$ & 0 \\
\hline $\begin{array}{l}\text { Oleksander } \\
\text { Kulchytsky }\end{array}$ & territory & $\begin{array}{l}\text { origin } \\
\text { (race) }\end{array}$ & language & history & $\begin{array}{l}\text { culture, } \\
\text { religion }\end{array}$ & national messianism \\
\hline Yuri Pundyk & ----- & ---- & language & $\begin{array}{l}\text { historical } \\
\text { traditions }\end{array}$ & $\begin{array}{l}\text { culture, } \\
\text { religion }\end{array}$ & national consciousness \\
\hline $\begin{array}{c}\text { Stepan } \\
\text { Rudnytsky }\end{array}$ & territory & $\begin{array}{l}\text { origin } \\
\text { (race) }\end{array}$ & $\begin{array}{l}\text { language, } \\
\text { literature }\end{array}$ & $\begin{array}{l}\text { traditions, } \\
\text { history }\end{array}$ & culture & national ideology \\
\hline $\begin{array}{l}\text { Oleksander } \\
\text { Shulhyn }\end{array}$ & territory & $\begin{array}{l}\text { origin } \\
\text { (race) }\end{array}$ & language & history & $\begin{array}{l}\text { culture, } \\
\text { religion }\end{array}$ & national consciousness \\
\hline $\begin{array}{c}\text { Gregory } \\
\text { Vashchenko }\end{array}$ & territory & origin & language & traditions & culture & national consciousness \\
\hline
\end{tabular}

Having analyzed the data in the table, we can conclude that when considering the concept of "nation" Ukrainian diaspora scholars identified both objective and subjective attributes. Most researchers ranked the race, geographical location or territory, culture, language, tradition, history, religion to objective factors. Subjective characteristics included national consciousness, national messianism, and freedom.

Conclusion. Consequently, in view of the theoretical approaches and concepts considered in understanding the concept of "nation", it can be noted that this phenomenon is complex and multidimensional. There are different approaches to determining the essence of the nation: some researchers consider it as an ethnic community either as a state or as a social community; others - as an imaginary commu- nity, as a linguistic-cultural community or as a spiritual, "holy" community. We have analyzed in detail the objective and subjective features of the nation, with the emphasis on the research of Ukrainian diaspora scholars, since their scientific achievements have not been sufficiently studied and covered in pedagogical studies.

The article also provides a rather schematic sketch of the evolution of the development and formation of the concepts of value, defined different approaches to understanding the concept of "value" by philosophers, sociologists, and educators. However, an analysis of the concept of "value", the concept of "nation" does not exhaust the fullness of the problem, but they reflect some ideas and understanding about the further consideration of the definitions we examine.

\section{ЛIТЕРАТУРА}

1. Альтер П. Нація: проблема визначення / Петер Альтер 2. Андерсон Б. Уявлені спільноти. Міркування щодо походження // Націоналізм: Антологія / Упоряд. О. Проценко, В. Лісовий. -К.: Смолоскип, 2000. - С. 580-592.

й поширення націоналізму / Бенедикт Андерсон. - Київ: “Критика", 2001.-271 с. 
3. Васькович Г. Об'єктивні і суб'єктивні ознаки нації / Г. Васькович. - Мюнхен. $-1964 .-20$ с.

4. Ващенко Г. Виховання волі і характеру / Г. Ващенко. - К.: “Школяр", 1999. - 385 с.

5. Гердер Й. Мова і національна індивідуальність / Йоган Г. Гердер // Націоналізм: Антологія / Упоряд. О. Проценко, В. Лісовий. - К.: Смолоскип, 2000. - С. 37-45.

6. Геллнер Е. Нації та націоналізм / Ернест Геллнер // Націоналізм: Антологія / Упоряд. О. Проценко, В. Лісовий. - К.: Смолоскип, 2000. - С. 292-310.

7. Гіденс Е. Соціологія / Ентоні Гіденс; [пер. 3 англ. В. Шевкун, А. Олійник]. - К.: Основи, $-1999 .-726$ с.

8. Дьюи Дж. Введение в философию воспитания / Дж. Дьюи. М. $-1921 .-63 \mathrm{c}$.

9. Княжинський А. Дух нації: соціологічно-етнопсихологічна студія / А. Княжинський. - Н-Й - Філадельфія - Мюнхен: Видано Наук. т-вом ім. Шевченка в ЗДА, 1959. - 291 с.

10. Крупницький Б. Історіознавчі проблеми історії України / Б. Крупницький. - Мюнхен: Український Вільний Університет, 1959. - 232 с. [Електронний ресурс]. - Режим доступу: http://diasporiana.org.ua/istoriya/9308-krupnitskiy-bistorioznavchi-problemi-istoriyi-ukrayini-zbirnik-stattey/

11. Кульчицький O. Психодидактичні аспекти українознавчої освіти в діаспорі //Педагогічні проблеми та дидактичні поради (матеріали Вишкільного Курсу для учителів суботніх шкіл). Мюнхен. - Вид-во: УВУ. - 1969. - С. 18-39.

12. Липинський В. Листи до братів-хліборобів // Вишкільний курс / Уложив проф. Г. Васькович. - Брюссель. - Мюнхен. Лондон. - Нью-Йорк. - Торонто: Вид-во СУМ, 1976/77. - Ч 2. - C. 41-117.

13. Маслоу А. Психология бытия / А. Маслоу. - М.: “Рефл-бук”, 1997. $-300 \mathrm{c}$.
14. Майнеке Ф. Загальний погляд на націю, національну державу і космополітизм / Фрідріх Майнеке // Націоналізм: Антологія / Упоряд. О. Проценко, В. Лісовий. - К.: Смолоскип, 2000. C. 503-514.

15. Митрополит Іларіон. Книга нашого буття на чужині. Вінніпег: Українське наукове богословське товариство, 1956. $-167 \mathrm{c}$.

16. Ницше Ф. Так говорил Заратустра / Н. Фридрих; [пер. с нем.]. - М.: Интербук, 1990. - 301 с.

17. Пундик Ю. Український націоналізм /Юрій Пундик. - Париж: Націоналістичне видавництво в Свропі, 1966. - 96 с.

18. Ренан Е. Що таке нація / Ернест Ренан // Націоналізм: Антологія / Упоряд. О. Проценко, В. Лісовий. - К.: Смолоскип, 2000. - С. 107-120.

19. Риккерт Г. Науки о природе и науки о культуре / Г. Риккерт. М.: Республика, 1998. - 413 с.

20. Риккерт Г. Философия жизни / Г. Риккерт; [пер. с нем.]. - К.: "Ника-Центр", 1998. - 512 с.

21. Роджерс К. Вчитися бути вільним / Карл Роджерс // Гуманістична психологія: Антологія /Упоряд. Р. Ткач, Г. Балл. - Т.І. Гуманістичні підходи в західній психології ХХ ст. - К.: "Пульсари", - 2001. -252 с.

22. Рудницький С. До основ українського націоналізму / Степан Рудницький. - 2-ге вид. - Відень - Прага, 1923. - 162 с.

23. Шульгін О. "Нація” і “національність” // Науковий збірник Укр. вільного ун-ту в Мюнхене. Ювілейне видання. Мюнхен: Druck "Logos", 1956. - T. VI. - С. 280-295.

24. Янів В. Нариси до історії української етнопсихології / Упорядкував М. Шафовал. - 2-ге вид. перероб. і доп. К.: Знання, 2006. - 341 с.
1. Alter P. Nation: the problem of definition // Nationalism: Anthology / edited by O. Protsenko, V.Lisoviy. - K.: Smoloskyp, $2000-$ P. 580-592.

2. Anderson B. Imagined Communities. - Kyiv: “Criticism”, 2001. $271 \mathrm{p}$.

3. DeweyJ. Introduction to the philosophy of upbringing.-M.-1921.-63p.

4. Gellner E. Nations and Nationalism // Nationalism: Anthology / edited by O. Protsenko, V. Lisoviy. - K.: Smoloskyp, $2000-$ P. 292-310.

5. Giddens A. Sociology / Per. from English V. Shevkun, A. Oliynyk. - K.: Fundamentals. $-1999 .-726$ p.

6. Herder J. Language and National Identity // Nationalism: Anthology / edited by O. Protsenko, V. Lisoviy. - K.: Smoloskyp, 2000. P. 37-45.

7. Knyazhinsky A. The Spirit of the Nation: Sociological and ethnopsychological studio. - NJ - Philadelphia - Munich: Published by Sci. Shevchenko in the State Duma, 1959. - 291 p.

8. Krupnytsky B. Historical problems of the history of Ukraine. Collection of articles. - Munich: Ukrainian Free University, 1959. - 232 p. [E. resource]. - Access mode: http://diasporiana.org.ua /istoriya/9308-krupnitskiy-b-istorioznavchi-problemi-istoriyiukrayini-zbirnik-stattey/

9. Kulchytsky O. Psychodidactic aspects of Ukrainian-speaking education in the diaspora // Pedagogical problems and didactic advice (materials of the Vocational School for teachers of Saturday schools). -Munich. - Type: Ukrainian Free University. - 1969. P. 18-39.

10. Lypynsky V. Letters to Brothers-Agrarians // school course / edited by prof. G. Vaskovich - Brussels. - Munich. - London. - NJ. Toronto: Published by CYM, 1976/77. - Part 2. - P. 41-117.

\section{ENCES}

11. Maslow A. Toward a psychology of being. - M.: "Refl-Beech", 1997. $-300 \mathrm{p}$.

12. Meinecke F. Cosmopolitanism and the National State // Nationalism: Anthology / edited by O. Protsenko, V. Lisoviy. K.: Smoloskyp, 2000. - P. 503-514.

13. Metropolitan Ilarion. The book of our being in a foreign country. Winnipeg: Ukrainian Scientific Theological Society, 1956. - 167 p. 14. Nietzsche F. So said Zarathustra. - M.: Interbuk, 1990. - 301 p.

15. Renan E. What is a nation? // Nationalism: Anthology / edited by O. Protsenko, V. Lisoviy. - K.: Smoloskyp, 2000. - P. 107-120.

16. Rickert H. About nature science and culture of science. - M.: Republic. $-1998 .-413$ p.

17. Rickert H. Philosophy of life. - K.: "Nika-Center", 1998.-512 p.

18. Rogers C. Freedom to Learn//Humanistic Psychology: Anthology ledited by R.Tkach, G.Ball.-Vol.I.Humanistic approaches in western psychology of the twentieth century.-K.: Pulsari.-2001.-251p.

19. Rudnytsky S. To the basics of Ukrainian nationalism. - 2nd form. - Vienna - Prague, 1923. - 162 p.

20. Pundyk Yu. Ukrainian nationalism. - Paris: Nationalist Publishing House in Europe, 1966. - 96 p.

21. Shulhyn O. "Nation" and "nationality" // Scientific collection Ukr. free un-tu in Munich. Jubilee Edition. - Munich: Druck "Logos", 1956. - T. VI. - P. 280-295.

22. Vashchenko G. Education of the will and character. K.: "School pupil", 1999. - $385 \mathrm{p}$.

23. Vaskovich G. Objective and subjective features of the nation. Munich - 1964. - 20 p.

24. Yaniv V. Essays on the history of Ukrainian ethnopsychology / Arranged M. Shafoval. - 2nd form. processing and add K.: Knowledge, 2006. - 341 p.

\section{Сущностные характеристики национальных ценностей в философской и психолого-педагогической литературе}

\section{О. 3. Глушко}

Аннотация. В статье уточняются сущностные, общие характеристики понятий “ценности”, “нация”, “национальные ценности”. Это исследование основывается на работах всемирно известных философов, психологов, социологов, педагогов, а также ученых украинской диаспоры. Определены ключевые компоненты понятия “нация" исходя из анализа философской и психологопедагогической литературы. На основе анализа психолого-педагогической литературы представителей украинской диаспоры были выделены объективные и субъективные компоненты понятия “нации”.

Ключевые слова: иченности, национальные иенности, нация, объективные и субъективные компоненты нации, украинская duacnopa. 